\title{
Xenia studies in exotic and indigenous almond (Prunus amygdalus L.) varieties of Kashmir, India
}

\author{
Shabeena Majid \\ Dryland Agricultural Research Station, Srinagar, SKUAST-Kashmir, Srinagar (Kashmir), India \\ Amit Kumar* \\ Division of Fruit Science, SKUAST-Kashmir, Shalimar Campus, Srinagar (Kashmir), India \\ Sabia Bashir \\ Dryland Agricultural Research Station, Srinagar, SKUAST-Kashmir, Srinagar (Kashmir), India \\ Seerat-ul-Nisa \\ Dryland Agricultural Research Station, Srinagar, SKUAST-Kashmir, Srinagar (Kashmir), India \\ Asima Amin \\ KVK, Srinagar, SKUAST-Kashmir (Kashmir), India \\ Shaheena Ahmad Nagoo \\ Temperate Sericulture Research Institute, Mirgund, SKUAST-Kashmir, Srinagar \\ (Kashmir), India \\ Zahida Rashid \\ Dryland Agricultural Research Station, Srinagar, SKUAST-Kashmir, Srinagar (Kashmir), India \\ Z. A. Dar \\ Dryland Agricultural Research Station, Srinagar, SKUAST-Kashmir, Srinagar (Kashmir), India \\ Saima Paul \\ KVK, Kulgam, SKUAST-Kashmir (Kashmir), India \\ ${ }^{*}$ Corresponding author. Email: khokherak@rediffmail.com

\begin{abstract}
Pollination is very important to obtain an economic yield, and the selection of pollinizer with suitable quality and quantity of pollen is an essential practice in different fruit plants. The effects of pollen parent on kernel and nut characters are known to occur in several nut crops and to determine the best pollinizer and effect of pollen source on the nut and kernel quality of almond (Prunus amygdalus L.). The present investigation was carried out at the experiment farm of Dryland Agriculture Research Station (DARS), SKUASTKashmir for two consecutive years, i.e. 2008 and 2009. Various cross combinations were made among nine almond (three exotic and six indigenous) varieties/selections which are compatible with each other. Their nut and kernel characteristics were determined and observed maximum nut weight $(2.21 \mathrm{~g})$, nut length $(39.78 \mathrm{~mm})$ and nut breadth $(20.33$ $\mathrm{mm})$, kernel weight $(1.28 \mathrm{~g})$, kernel length $(28.63 \mathrm{~mm})$ and kernel breadth $(12.61 \mathrm{~mm})$ and shelling percentage (57.99\%). In the present study it has been observed that the parent with big nut and kernel size and weight influenced the nut and kernel size; nut and kernel weight of the recipient parent significantly $(p \leq 0.05)$.
\end{abstract}

Keywords: Almond, Exotic, Indigenous, Selections, Varieties, Xenia

\section{INTRODUCTION}

Almond, one of the most important nut fruit in the world, is mainly grown on sloppy land and under rain-fed conditions in India with very low productivity (Sharma and Joolka, 2000) mainly in Jammu and Kashmir and Himachal Pradesh. Grown on an area of about 5588 hectares, the production of almond in the state of Jammu and Kashmir is about 10,326 MT (Anonymous, 2019). Out of the total production of the country (13.69 thousand tonnes), more than 90 per cent of the produce comes from Kashmir with low productivity as com-

\section{Article Info}

https://doi.org/10.31018/

jans.vi.2266

Received: April 29, 2020

Revised: May 31, 2020

Accepted: June 9, 2020

\section{How to Cite}

Majid, S. et al. (2020) Xenia studies in exotic and indigenous almond (Prunus amygdalus L.) varieties of Kashmir, India. Journal of Applied and Natural Science, 12(2): $244-251$ https://doi.org/10.31018/ jans.vi.2266 
var with sufficient overlapping of flowering periods to ensure adequate cross-pollination and fruit set. Fertilization is an important factor in almond production because the commercial part is a seed that results from fertilized ovule. Effects of a particular pollen parent on seed (xenia) or fruit (metaxenia) characteristics are known to occur in several nut crops. Xenia and metaxenia effect have been observed in a chestnut (Crane and Iwakiri, 1980), pecan (Marquard, 1988) and almond (Vezvaie and Jackson, 1995; Kumar and Das, 1996). Cross-pollination increases nut and kernel weight and decreases blank percentage in different nut crops (Rahemi and Javadi, 2001). Thus maximum orchard efficiency depends on the proper combination of compatible cultivars, favourable weather and proper pollinator management. Considering this, it was felt imperative to study whether or not the pollen parent affects economically important nut and kernel characters in almond. The present study was conducted with cross-compatible combinations with various almond introduced varieties from abroad and SKUAST, Kashmir released selections.

\section{MATERIALS AND METHODS}

Experimental material and location: The present investigation was carried out with cross combinations of nine almond (three exotic and six indigenous) varieties/selections at experiment farm of Dryland Agriculture Research Station (DARS), SKUAST-Kashmir, Jammu and Kashmir for two consecutive years, i.e. 2008 and 2009. The experimental farm is situated at a latitude of $34^{\circ} 05^{\prime} \mathrm{N}$ and longitude of $74^{\circ} 50^{\prime} \mathrm{E}$ and at an altitude of $1640 \mathrm{~m}$ amsl with the temperate region having cold conditions from November to February. The experimental was comprised of nine almond varieties viz. Pranyaj $\left(V_{1}\right)$, Merced $\left(V_{2}\right)$, Primorskij $\left(V_{3}\right)$, Mukhdoom $\left(\mathrm{V}_{4}\right)$, Waris $\left(\mathrm{V}_{5}\right)$, Shalimar $\left(\mathrm{V}_{6}\right)$, KD-03 $\left(\mathrm{V}_{7}\right), \mathrm{KD}-05\left(\mathrm{~V}_{8}\right)$ and $\mathrm{KD}-06\left(\mathrm{~V}_{9}\right)$ planted in 1988. Plants of uniform size and vigour were selected randomly, and all the trees were kept under similar cultural practices to ensure uniform growth as per package and practices (Anonymous, 2018). Samples were collected from mature nuts and kernels obtained from the cross combinations given in Table 1.

Observation recorded and data analysis: Observations were recorded on nut and kernel characters. Nut weight and kernel weight of fifteen nuts were taken with the help of top pan balance, the averaged value was worked out and expressed in grams. Nut (length and breadth) and kernel (length and breadth) were measured of fifteen nuts and kernels, the average was worked out and expressed in $\mathrm{mm}$. The shelling percentage was worked out by multiplying the ratio of kernel weight and nut weight with 100 and expressed in percentage.

Data collected on various parameters were computed and statistically analyzed as per the procedure given by Snedecor and Cochran (1994). The level of significance was tested for the different variables at 5 percent.

\section{RESULTS AND DISCUSSION}

The immediate effect of pollen on the tissues of nuts and kernel has received much attention in several plants of horticultural importance (Denney, 1992). Most of the cultivars are self-incompatible in almond. Therefore some other pollinizer cultivars were used for commercial fruit production.

Effect of pollen source on nut weight and nut size: Data on the effect of pollen source on nut weight and nut size of different female varieties are shown in Table 2.

Cross combinations with Pranyaj of different pollen source depicted that maximum nut weight was with Primorskij ( $2.21 \mathrm{~g}$ and $2.17 \mathrm{~g}$, respectively) as a pollen donor during the year 2008 and 2009, respectively, which was significantly $(p \leq 0.05)$ different than other pollen sources followed by Waris $(2.08 \mathrm{~g})$ and KD-06 $(2.07 \mathrm{~g})$ in the first year and KD-06 $(2.10 \mathrm{~g})$ and Waris $(2.09 \mathrm{~g})$ in the second year. Minimum nut weight $(2.00 \mathrm{~g})$ in the first year was recorded when Merced and Mukhdoom were used as pollen donors whereas in the se-

Table 1. Crossing plan among different almond varieties/selections.

\begin{tabular}{|c|c|c|c|c|c|c|c|c|c|}
\hline $0^{1}$ & $V_{1}$ & $V_{2}$ & $V_{3}$ & $V_{4}$ & $V_{5}$ & $V_{6}$ & V7 & V8 & V9 \\
\hline$V_{1}$ & $V_{1} V_{1}$ & $V_{1} V_{2}$ & $V_{1} V_{3}$ & $V_{1} V_{4}$ & $V_{1} V_{5}$ & $V_{1} V_{6}$ & $V_{1} V_{7}$ & $\mathrm{~V}_{1} \mathrm{~V}_{8}$ & $V_{1} V_{9}$ \\
\hline$V_{2}$ & & $\mathrm{~V}_{2} \mathrm{~V}_{2}$ & $V_{2} V_{3}$ & $\mathrm{~V}_{2} \mathrm{~V}_{4}$ & $\mathrm{~V}_{2} \mathrm{~V}_{5}$ & $\mathrm{~V}_{2} \mathrm{~V}_{6}$ & $\mathrm{~V}_{2} \mathrm{~V}_{7}$ & $\mathrm{~V}_{2} \mathrm{~V}_{8}$ & $V_{2} V_{9}$ \\
\hline$V_{3}$ & & & $V_{3} V_{3}$ & $V_{3} V_{4}$ & $V_{3} V_{5}$ & $\mathrm{~V}_{3} \mathrm{~V}_{6}$ & $V_{3} V_{7}$ & $V_{3} V_{8}$ & $V_{3} V_{9}$ \\
\hline$V_{4}$ & & & & $\mathrm{~V}_{4} \mathrm{~V}_{4}$ & $\mathrm{~V}_{4} \mathrm{~V}_{5}$ & $\mathrm{~V}_{4} \mathrm{~V}_{6}$ & $\mathrm{~V}_{4} \mathrm{~V}_{7}$ & $\mathrm{~V}_{4} \mathrm{~V}_{8}$ & $\mathrm{~V}_{4} \mathrm{~V}_{9}$ \\
\hline$V_{5}$ & & & & & $\mathrm{~V}_{5} \mathrm{~V}_{5}$ & $V_{5} V_{6}$ & $V_{5} V_{7}$ & $V_{5} V_{8}$ & $V_{5} V_{9}$ \\
\hline$V_{6}$ & & & & & & $V_{6} V_{6}$ & $V_{6} V_{7}$ & $V_{6} V_{8}$ & $V_{6} V_{9}$ \\
\hline$v_{7}$ & & & & & & & $V_{7} V_{7}$ & $V_{7} V_{8}$ & $V_{7} V_{9}$ \\
\hline$v_{8}$ & & & & & & & & $V_{8} V_{8}$ & $V_{8} V_{9}$ \\
\hline$V_{9}$ & & & & & & & & & $\mathrm{~V}_{9} \mathrm{~V}_{9}$ \\
\hline
\end{tabular}


Majid, S. et al. / J. Appl. \& Nat. Sci. 12(2): 244 - 251 (2020)

cond year minimum nut weight $(2.05 \mathrm{~g})$ was recorded with KD-03 and KD-05 used as pollen donors. Maximum nut length during both the years of study was recorded in Pranyaj x Primorskij (39.23 $\mathrm{mm}$ and $39.78 \mathrm{~mm}$, respectively) which was significantly higher than other varieties/selections. In contrast, minimum nut length was recorded in
Pranyaj x KD-03 (36.81 mm) and Pranyaj x KD-05 $(36.81 \mathrm{~mm})$ in the first year and in Pranyaj $x$ Shalimar $(37.17 \mathrm{~mm})$ in the second year of study. Pranyaj $x$ Waris $(20.22 \mathrm{~mm}$ and $20.12 \mathrm{~mm}$ ) noticed maximum nut breadth during both the years of study which differed significantly $(p \leq 0.05)$ from other cross combinations. In contrast, minimum

Table 2. Effect of pollen sources on nut weight and nut size in almond.

\begin{tabular}{|c|c|c|c|c|c|c|c|}
\hline \multirow{3}{*}{ Female parent } & \multirow{3}{*}{$\begin{array}{l}\text { Pollen } \\
\text { source }\end{array}$} & \multirow{2}{*}{\multicolumn{2}{|c|}{ Nut weight (g) }} & \multicolumn{4}{|c|}{ Nut size (mm) } \\
\hline & & & & \multicolumn{2}{|c|}{ Length } & \multicolumn{2}{|c|}{ Breadth } \\
\hline & & $1^{\text {st }}$ year & $2^{\text {nd }}$ year & $1^{\text {st }}$ year & $2^{\text {nd }}$ year & $1^{\text {st }}$ year & $2^{\text {nd }}$ year \\
\hline \multirow[t]{8}{*}{ Pranyaj $x$} & Merced & 2.00 & 2.07 & 36.82 & 37.20 & 19.49 & 19.27 \\
\hline & Primorskij & 2.21 & 2.17 & 39.23 & 39.78 & 19.01 & 19.20 \\
\hline & Mukhdoom & 2.00 & 2.07 & 36.84 & 37.22 & 19.50 & 19.52 \\
\hline & Waris & 2.08 & 2.09 & 36.84 & 37.18 & 20.22 & 20.12 \\
\hline & Shalimar & 2.03 & 2.07 & 36.89 & 37.17 & 19.48 & 19.21 \\
\hline & KD-03 & 2.02 & 2.05 & 36.81 & 37.19 & 19.46 & 19.23 \\
\hline & KD-05 & 2.03 & 2.05 & 36.81 & 37.20 & 19.47 & 19.19 \\
\hline & KD-06 & 2.07 & 2.10 & 36.83 & 37.21 & 19.48 & 19.25 \\
\hline $\mathrm{CD}_{0.05}$ & & 0.11 & 0.05 & 0.032 & 0.02 & 0.01 & 0.012 \\
\hline \multirow[t]{7}{*}{ Merced $\mathrm{x}$} & Primorskij & - & - & - & - & - & - \\
\hline & Mukhdoom & 1.96 & 1.98 & 35.98 & 35.05 & 19.28 & 19.39 \\
\hline & Waris & 2.06 & 2.04 & 35.82 & 34.87 & 20.33 & 20.08 \\
\hline & Shalimar & 1.84 & 1.83 & 35.88 & 35.00 & 17.93 & 18.10 \\
\hline & KD-03 & 1.85 & 1.86 & 35.96 & 35.02 & 18.26 & 18.12 \\
\hline & KD-05 & 1.82 & 1.81 & 35.92 & 34.96 & 18.06 & 18.20 \\
\hline & KD-06 & 1.80 & 1.80 & 35.94 & 34.94 & 19.08 & 18.66 \\
\hline $\mathrm{CD}_{0.05}$ & & 0.09 & 0.05 & 0.29 & 0.21 & 0.14 & 0.56 \\
\hline \multirow[t]{6}{*}{ Primorskij x } & Mukhdoom & 2.21 & 2.15 & 39.78 & 40.12 & 19.12 & 19.33 \\
\hline & Waris & 2.20 & 2.17 & 39.77 & 40.12 & 20.11 & 20.01 \\
\hline & Shalimar & 2.19 & 2.16 & 39.77 & 40.13 & 18.76 & 18.78 \\
\hline & KD-03 & 2.20 & 2.17 & 39.77 & 40.12 & 18.77 & 18.80 \\
\hline & KD-05 & 2.21 & 2.16 & 39.78 & 40.12 & 18.77 & 18.87 \\
\hline & KD-06 & 2.23 & 2.19 & 39.76 & 40.10 & 19.08 & 19.00 \\
\hline $\mathrm{CD}_{0.05}$ & & 0.01 & 0.01 & NS & NS & 0.14 & 0.10 \\
\hline \multirow[t]{5}{*}{ Mukhdoom x } & Waris & 2.00 & 2.07 & 32.33 & 32.87 & 20.38 & 20.12 \\
\hline & Shalimar & 1.96 & 2.10 & 34.29 & 35.68 & 19.44 & 19.55 \\
\hline & KD-03 & 1.97 & 2.08 & 30.32 & 31.24 & 19.43 & 19.44 \\
\hline & KD-05 & 1.95 & 2.06 & 30.30 & 31.10 & 19.40 & 19.38 \\
\hline & KD-06 & 1.96 & 2.08 & 30.31 & 31.13 & 19.41 & 19.40 \\
\hline $\mathrm{CD}_{0.05}$ & & 0.013 & 0.013 & 0.015 & 0.01 & 0.01 & 0.01 \\
\hline \multirow[t]{4}{*}{ Waris $\mathrm{x}$} & Shalimar & 2.11 & 2.06 & 34.10 & 35.01 & 20.34 & 20.16 \\
\hline & KD-03 & 2.10 & 2.06 & 32.31 & 31.11 & 20.35 & 20.16 \\
\hline & KD-05 & 2.11 & 2.07 & 32.30 & 31.41 & 20.36 & 20.17 \\
\hline & KD-06 & 2.12 & 2.07 & 32.31 & 31.10 & 20.35 & 20.15 \\
\hline $\mathrm{CD}_{0.05}$ & & 0.013 & NS & NS & 0.47 & 0.014 & 0.013 \\
\hline \multirow[t]{3}{*}{ Shalimar $\mathrm{x}$} & KD-03 & 1.82 & 1.79 & 34.58 & 35.17 & 17.14 & 17.13 \\
\hline & KD-05 & 1.83 & 1.80 & 34.57 & 35.16 & 17.17 & 17.87 \\
\hline & KD-06 & 1.81 & 1.81 & 34.55 & 35.19 & 17.10 & 17.57 \\
\hline $\mathrm{CD}_{0.05}$ & & NS & NS & NS & NS & NS & NS \\
\hline
\end{tabular}


nut breadth in the first year was obtained in Pranyaj $x$ Primorskij $(19.01 \mathrm{~mm})$ and in the second year in Pranyaj x KD-06 (19.19 mm).

Data in Table 2 depicted the significant results on the effect of pollen source on various nut characters of Merced. No fruit set was obtained in a cross combination of Merced $x$ Primorskij in both the year of study. Merced $x$ Waris recorded maximum nut weight $(2.01 \mathrm{~g}$ and $2.00 \mathrm{~g})$, nut breadth (20.33 $\mathrm{mm}$ and $20.08 \mathrm{~mm}$ ) and kernel weight $(1.03 \mathrm{~g}$ and $1.02 \mathrm{~g})$ during both the years of study which differed significantly from other varieties/ selections. Maximum nut length was observed in Merced x Mukhdoom $(35.98 \mathrm{~mm}$ and $35.05 \mathrm{~mm}$, respectively) in both the years, which was statistically at par with all the varieties. Minimum nut weight $(1.80 \mathrm{~g}$ and $1.80 \mathrm{~g})$, nut length $(35.82 \mathrm{~mm}$ and $34.87 \mathrm{~mm})$, nut breadth $(17.93 \mathrm{~mm}$ and 18.10 $\mathrm{mm})$ and kernel weight $(0.98 \mathrm{~g}$ and $0.99 \mathrm{~g})$ in Merced was recorded when KD-06, Waris, Shalimar and KD-05 were used as a pollen source during both the years, respectively.

Effect of different pollen source on nut characters of Primorskij is presented in Table 2. Cross combination of Primorskij x KD-06 (2.23 g and $2.19 \mathrm{~g}$ ) recorded highest nut weight in both the years of study which differed significantly from others whereas lowest nut weight was observed with Primorskij $x$ Shalimar $(2.19 \mathrm{~g})$ in the first year and Primorskij x Mukhdoom $(2.15 \mathrm{~g})$ in the second year. Maximum nut length $(39.78 \mathrm{~mm})$ in Primorskij was recorded with Mukhdoom and KD-05 used as pollen source in the first year and in the second year with Shalimar $(40.13 \mathrm{~mm})$ as pollen source. Minimum nut length was recorded in Primorskij x KD-06 (39.76 mm and $40.10 \mathrm{~mm}$ ) in both the year, respectively. Maximum and minimum nut breadth was recorded in Primorskij $x$ Waris $(20.11 \mathrm{~mm}$ and $20.01 \mathrm{~mm}$ ) and Primorskij $x$ Shalimar $(18.76 \mathrm{~mm}$ and $18.78 \mathrm{~mm}$ ) during both the years of study.

Data in Table 2 revealed that there was a significant effect of cross combinations on nut weight, nut size, kernel size, shelling percentage of Mukhdoom however, kernel weight and organoleptic evaluation was non-significant ( $p \leq 0.05$ ). Maximum and minimum nut weight was recorded in Mukhdoom $x$ Waris $(2.00 \mathrm{~g})$ and Mukhdoom $x$ $\mathrm{KD}-05(1.95 \mathrm{~g})$ during the first year whereas in the second year Mukhdoom x Shalimar $(2.10 \mathrm{~g})$ recorded maximum and Mukhdoom x KD-05 (2.06 g) recorded minimum nut weight. Maximum nut length and nut breadth were recorded in Mukhdoom x Shalimar (34.29 $\mathrm{mm}$ and $35.68 \mathrm{~mm}$ ) and Mukhdoom x Waris $(20.38 \mathrm{~mm}$ and 20.12 $\mathrm{mm}$ ) during both the year of study whereas minimum nut length $(30.30 \mathrm{~mm}$ and $31.10 \mathrm{~mm})$ and nut breadth $(19.40 \mathrm{~mm}$ and $19.38 \mathrm{~mm}$ ) was obtained in Mukhdoom x KD-05, respectively during both the years.
Effect of different pollen source showed significant results on Waris for nut breadth, kernel length, shelling percentage during both the years and for nut weight in the first year and for nut length in the second year (Table 2). Nut weight ranged from $2.10 \mathrm{~g}$ (Waris $x$ KD-03) to $2.12 \mathrm{~g}$ (Waris $\times$ KD-06) during the first year and in the second year $2.06 \mathrm{~g}$ (Waris $x$ Shalimar and Waris $x$ KD-03) to $2.07 \mathrm{~g}$ (Waris $x$ KD-06 and Waris $x$ KD-5). Maximum nut length with Shalimar $(34.10 \mathrm{~mm}$ and $35.01 \mathrm{~mm}$ ) used as a pollen source for Waris during both the years which differed significantly from other pollen sources. In contrast, minimum nut length was recorded with $\mathrm{KD}-05(32.30 \mathrm{~mm})$ in the first year and with KD-06 $(31.10 \mathrm{~mm})$ in the second year, when used as a pollen source. Waris $\times \mathrm{KD}-05$ measured maximum nut breadth $(20.36 \mathrm{~mm}$ and $20.17 \mathrm{~mm}$ ) during both the years whereas minimum nut breadth in Waris $x$ Shalimar $(20.34 \mathrm{~mm})$ in the first year and in Waris x KD-06 (20.15 mm) in the second year.

Non-significant results were obtained for all the nut characters of Shalimar with different pollen source. Nut weight ranged between $1.81 \mathrm{~g}$ (Shalimar $x$ KD-06) to $1.83 \mathrm{~g}$ (Shalimar x KD-05) and $1.79 \mathrm{~g}$ (Shalimar $x$ KD-03) to $1.81 \mathrm{~g}$ (Shalimar $x$ KD-06) during both the years, respectively. Nut length ranges between $34.55 \mathrm{~mm}$ (Shalimar x KD$06)$ to $34.58 \mathrm{~mm}$ (Shalimar $\mathrm{x} \mathrm{KD-03)}$ and 35.16 $\mathrm{mm}$ (Shalimar x KD-05) to 35.19 (Shalimar x KD06) whereas nut breadth ranges between 17.10 (Shalimar $x$ KD-06) to 17.17 (Shalimar $x$ KD-05) and 17.13 (Shalimar $x$ KD-03) to 17.87 (Shalimar $x$ KD-05) during both the years of study.

In the earlier reports, it has been observed that size of nuts (different nut crops) produced was always in the direction of the pollen parent (Crane and Iwakiri, 1980, Golzari et al., 2016). In the present study also pollen from the cultivar that produced relatively large nuts when applied to a cultivar normally producing small nuts brought about an increase in the size of a nut of the recipient parent. The present findings are in the agreements with Vezvaei and Jackson (1995), where they obtained heavier and bigger nuts from Price variety of almond when Keane variety was used as donor parents. Kumar and Das (1996) also reported that nut size index was significantly increased in a small nut parent 'Drake' on pollination with large nut parents 'Nonpareil'.

Effect of pollen source on kernel weight and kernel size: Highest kernel weight was observed with Primorskij (1.26 g and $1.25 \mathrm{~g}$, respectively) as a pollen donor during both the year, which significantly differed than other varieties. In contrast, the lowest kernel weight was obtained with Merced (1.13 $\mathrm{g}$ and $1.16 \mathrm{~g}$, respectively) as a pollen donor during both the year of study (Table 3 ). Maximum kernel length and kernel breadth during both the year of study were obtained from the 
Majid, S. et al. / J. Appl. \& Nat. Sci. 12(2): 244 - 251 (2020)

cross combinations of Pranyaj $x$ Primorskij (28.60 $\mathrm{mm}$ and $28.77 \mathrm{~mm}$ ) and Pranyaj $x$ Waris (12.61 $\mathrm{mm}$ and $12.43 \mathrm{~mm}$ ), respectively which differs significantly from other varieties/selections whereas minimum kernel length and kernel breadth were recorded in Pranyaj x KD-05 (26.81 mm and 26.83 $\mathrm{mm}$ ) and Pranyaj $x$ Merced (12.09 mm and 11.92 $\mathrm{mm}$ ) during both the years, respectively.
Maximum kernel length and kernel breadth were recorded in cross combinations of Merced $x$ Mukhdoom (26.67 $\mathrm{mm}$ and $26.28 \mathrm{~mm}$ ) and Merced $x$ Waris (12.60 $\mathrm{mm}$ and $12.42 \mathrm{~mm}$ ) whereas minimum kernel length and kernel breadth were obtained from Merced $x$ Waris (26.59 $\mathrm{mm}$ and $26.22 \mathrm{~mm}$ ) and Merced x KD-06 $(11.55 \mathrm{~mm}$ and $11.31 \mathrm{~mm})$ during both the years

Table 3. Effect of pollen sources on kernel weight and kernel size in almond.

\begin{tabular}{|c|c|c|c|c|c|c|c|}
\hline \multirow{3}{*}{ Female parent } & \multirow{3}{*}{$\begin{array}{l}\text { Pollen } \\
\text { source }\end{array}$} & \multirow{2}{*}{\multicolumn{2}{|c|}{ Kernel weight (g) }} & \multicolumn{4}{|c|}{ Kernel size $(\mathrm{mm})$} \\
\hline & & & & \multicolumn{2}{|c|}{ Length } & \multicolumn{2}{|c|}{ Breadth } \\
\hline & & $1^{\text {st }}$ year & $2^{\text {nd }}$ year & $1^{\text {st }}$ year & $2^{\text {nd }}$ year & $1^{\text {st }}$ year & $2^{\text {nd }}$ year \\
\hline \multirow[t]{8}{*}{ Pranyaj $\mathrm{x}$} & Merced & 1.13 & 1.16 & 26.85 & 26.88 & 12.09 & 11.92 \\
\hline & Primorskij & 1.26 & 1.25 & 28.60 & 28.77 & 12.10 & 11.96 \\
\hline & Mukhdoom & 1.15 & 1.21 & 26.83 & 26.86 & 12.10 & 11.95 \\
\hline & Waris & 1.14 & 1.18 & 26.83 & 26.87 & 12.61 & 12.43 \\
\hline & Shalimar & 1.15 & 1.18 & 26.84 & 26.85 & 12.10 & 11.98 \\
\hline & KD-03 & 1.16 & 1.18 & 26.83 & 26.87 & 12.12 & 11.98 \\
\hline & KD-05 & 1.15 & 1.17 & 26.81 & 26.83 & 12.11 & 11.98 \\
\hline & KD-06 & 1.15 & 1.17 & 26.85 & 26.87 & 12.11 & 11.96 \\
\hline $\mathrm{CD}_{0.05}$ & & 0.011 & 0.01 & 0.014 & 0.03 & 0.012 & 0.048 \\
\hline \multirow[t]{7}{*}{ Merced $\mathrm{x}$} & Primorskij & - & - & - & - & - & - \\
\hline & Mukhdoom & 1.01 & 1.01 & 26.67 & 26.28 & 11.58 & 11.32 \\
\hline & Waris & 1.08 & 1.06 & 26.59 & 26.22 & 12.60 & 12.42 \\
\hline & Shalimar & 1.00 & 1.00 & 26.60 & 26.27 & 11.57 & 11.33 \\
\hline & KD-03 & 1.02 & 1.00 & 26.66 & 26.24 & 11.56 & 11.32 \\
\hline & KD-05 & 0.98 & 0.99 & 26.61 & 26.25 & 11.58 & 11.32 \\
\hline & KD-06 & 1.01 & 1.01 & 26.64 & 26.24 & 11.55 & 11.31 \\
\hline $\mathrm{CD}_{0.05}$ & & 0.016 & 0.010 & NS & NS & 0.04 & 0.04 \\
\hline \multirow[t]{6}{*}{ Primorskij x } & Mukhdoom & 1.25 & 1.22 & 28.60 & 29.02 & 11.75 & 11.62 \\
\hline & Waris & 1.27 & 1.26 & 28.60 & 28.99 & 12.60 & 12.32 \\
\hline & Shalimar & 1.28 & 1.24 & 28.63 & 28.99 & 11.78 & 11.59 \\
\hline & KD-03 & 1.27 & 1.23 & 28.60 & 29.01 & 11.77 & 11.59 \\
\hline & KD-05 & 1.27 & 1.24 & 28.58 & 29.00 & 11.74 & 11.56 \\
\hline & KD-06 & 1.26 & 1.23 & 28.63 & 28.98 & 11.76 & 11.60 \\
\hline $\mathrm{CD}_{0.05}$ & & NS & NS & NS & NS & 0.013 & 0.022 \\
\hline \multirow[t]{5}{*}{ Mukhdoom x } & Waris & 0.94 & 0.95 & 22.40 & 22.52 & 12.40 & 12.31 \\
\hline & Shalimar & 0.85 & 0.89 & 24.90 & 25.11 & 11.01 & 11.12 \\
\hline & KD-03 & 0.86 & 0.90 & 22.04 & 22.45 & 11.24 & 11.11 \\
\hline & KD-05 & 0.86 & 0.93 & 22.05 & 22.50 & 10.97 & 11.09 \\
\hline & KD-06 & 0.86 & 0.92 & 22.08 & 22.47 & 11.22 & 11.24 \\
\hline $\mathrm{CD}_{0.05}$ & & NS & NS & 0.04 & 0.015 & 0.01 & 0.014 \\
\hline \multirow[t]{4}{*}{ Waris $\mathrm{x}$} & Shalimar & 1.02 & 1.02 & 25.76 & 26.02 & 12.67 & 12.43 \\
\hline & KD-03 & 1.02 & 1.02 & 22.77 & 22.98 & 12.60 & 12.41 \\
\hline & KD-05 & 1.00 & 1.01 & 22.74 & 22.97 & 12.59 & 12.39 \\
\hline & KD-06 & 1.00 & 1.01 & 22.76 & 22.99 & 12.58 & 12.40 \\
\hline $\mathrm{CD}_{0.05}$ & & NS & NS & 0.01 & 0.01 & NS & NS \\
\hline \multirow[t]{3}{*}{ Shalimar $\mathrm{x}$} & KD-03 & 0.90 & 0.91 & 25.77 & 26.27 & 11.33 & 11.11 \\
\hline & KD-05 & 0.88 & 0.90 & 25.77 & 26.28 & 10.86 & 10.99 \\
\hline & KD-06 & 0.87 & 0.89 & 25.77 & 26.26 & 11.13 & 11.23 \\
\hline $\mathrm{CD}_{0.05}$ & & NS & NS & NS & NS & NS & NS \\
\hline
\end{tabular}


of study, respectively however results were nonsignificant for kernel length in both the years (Table 3). Different pollen parents crossed with Primorskij depicts non-significant for kernel weight (Table 3). In the first year, kernel weight ranged from $1.25 \mathrm{~g}$ (Primorskij $x$ Mukhdoom) and $1.28 \mathrm{~g}$ (Primorskij $\mathrm{x}$ Shalimar) whereas in the second year ranged from $1.22 \mathrm{~g}$ (Primorskij $\mathrm{x}$ Mukhdoom) to $1.26 \mathrm{~g}$ (Primorskij x Waris). Non-significant results were observed for kernel length where maximum kernel length $(28.63 \mathrm{~mm})$ in the first year was recorded in Primorskij $x$ Shalimar and Primorskij $x$ KD-06 and minimum in Primorskij x KD-05 (28.58 mm). Maximum and minimum kernel length in the second year was recorded in Primorskij $\mathrm{x}$ Mukhdoom (29.02 mm) and Primorskij x KD-06 (28.98 mm). Primorskij $x$ Waris recorded maximum $(12.60 \mathrm{~mm}$ and $12.32 \mathrm{~mm}$ ) kernel breadth during both the year whereas the minimum was recorded in Primorskij x KD-05 (11.74 mm and $11.56 \mathrm{~mm})$ during both the years.

Non-significant effect ( $p \leq 0.05$ ) on kernel weight in both the years of study was noticed. However, the maximum kernel weight was recorded in Mukhdoom $x$ Waris $(0.94 \mathrm{~g}$ and $0.95 \mathrm{~g})$ in both the years whereas minimum kernel weight was recorded in Mukhdoom x Shalimar (0.85 $\mathrm{g}$ and 0.89 $g$, respectively) during both the years (Table 3 ). Maximum and minimum kernel length was recorded in Mukhdoom x Shalimar $(24.90 \mathrm{~mm}$ and 25.11 $\mathrm{mm}$ ) and Mukhdoom x KD-03 (22.04 mm and $22.45 \mathrm{~mm}$ ) during both the year of study whereas maximum and minimum kernel breadth was recorded in Mukhdoom x waris $(12.40 \mathrm{~mm}$ and 12.31 $\mathrm{mm}$ ) and Mukhdoom x KD-05 (10.97 mm and $11.09 \mathrm{~mm}$ ) in both the years.

The non-significant effect of pollen source was obtained on Waris for kernel weight which ranges between $1.00 \mathrm{~g}$ (Waris $\times$ KD-06 and Waris x KD05 ) to $1.02 \mathrm{~g}$ (Waris $x$ Shalimar and Waris $x$ KD03 ) in the first year and $1.01 \mathrm{~g}$ (Waris $x$ KD-06 and Waris $x$ KD-05) to $1.02 \mathrm{~g}$ (Waris $x$ Shalimar and Waris $x$ KD-03) in the second year of study (Table 3 ). Maximum and minimum kernel length was recorded in Waris $x$ Shalimar $(25.06 \mathrm{~mm}$ and 26.02 $\mathrm{mm})$ and Waris $x$ KD-05 (22.74 mm and 22.97 $\mathrm{mm}$ ), respectively during both the years. Nonsignificant results of kernel breadth depicted that in the first year Waris $x$ Shalimar $(12.67 \mathrm{~mm})$ scored maximum values and Waris $x$ KD-06 $(12.58 \mathrm{~mm})$ scored minimum values for kernel breadth whereas in the second year kernel breadth ranges between $12.39 \mathrm{~mm}$ (Waris $\mathrm{x}$ KD05) to 12.43 (Waris $x$ Shalimar).

During both the years of study, kernel weight ranges between $0.87 \mathrm{~g}$ (Shalimar x KD-06) to $0.90 \mathrm{~g}$ (Shalimar x KD-03) and $0.89 \mathrm{~g}$ (Shalimar x KD-06) to $0.91 \mathrm{~g}$ (Shalimar $\times \mathrm{KD}-03$ ). Data reveals kernel length of $25.77 \mathrm{~mm}$ recorded for all cross combination in the first year as compared to maximum kernel length of $26.28 \mathrm{~mm}$ recorded in Shalimar $\mathrm{x}$ $\mathrm{KD}-05(26.28 \mathrm{~mm})$ and minimum recorded in Shalimar x KD-06 $(26.26 \mathrm{~mm})$ in the second year. The kernel breadth ranged from $10.86 \mathrm{~mm}$ (Shalimar x KD-05) to 11.33 (Shalimar x KD-03) in the first year and ranges from $10.99 \mathrm{~mm}$ (Shalimar $x \mathrm{KD}-05$ ) to $11.23 \mathrm{~mm}$ (Shalimar $x \mathrm{KD}-06$ ) in the second year.

In the earlier studies, Kumar and Das (1996), Acar et al. (2016) on almond and Golzari et al. (2016) on walnut also reported big kernel size of the recipient parent when crossed with the bigger kernel size of the pollen parent.

Effect of pollen source on shelling percentage : Figure 1 depicts that during the first year of study, the highest shelling percentage was observed in Pranyaj x Mukhdoom $(57.83 \%$ ) as compared to lowest shelling percentage recorded in Pranyaj x KD-06 (55.71 \%) whereas, in the second year, maximum shelling percentage was observed in Pranyaj $x$ Mukhdoom (57.50 \%) and minimum recorded in Pranyaj $x$ Waris (54.87 \%) (Fig. 2). Merced $x$ KD-06 (56.12\% and $55.80 \%)$ scored maximum values for shelling percentage during both the years which was statistically at par with Merced x KD-05 (55.68\% and $55.02 \%$ ) whereas minimum shelling percentage was recorded in Merced $x$ Waris $(51.31 \%$ and $50.98 \%$ ) during both the years, respectively.

Different cross combinations Primorskij with pollen source depicts that maximum shelling percentage in the first year was scored in Primorskij $x$ Shalimar $(57.99 \%)$ which was statistically at par with Primorskij $x$ Waris (57.72 \%) and minimum in Primorskij x Mukhdoom (57.01\%) (Fig. 1). In the second year, results were non-significant however, maximum and minimum shelling percentage was obtained in Primorskij x Waris $(57.60 \%)$ and Primorskij x KD-05 (56.94 \%), respectively (Fig. 2).

Mukhdoom $x$ Waris revealed maximum shelling percentage $(47.12 \%$ and $45.89 \%)$ during both the years which differs significantly from other varieties whereas minimum shelling percentage was recorded in Mukhdoom x Shalimar $(43.87 \%$ and $42.85 \%$ ) in both the years.

Shelling percentage showed significant results when different pollen source was applied on Waris during both the years (Fig. 1 and 2). Maximum shelling percentage was recorded in Waris $x \mathrm{KD}$ $03(48.81 \%$ and $49.75 \%)$ during both the years whereas minimum shelling percentage was recorded in Waris x KD-06 (47.29 \% and $48.81 \%$ ) in both the years.

Shelling percentage of different cross combinations with Shalimar shows significant results. Shalimar x KD-06 (49.86 \%) reveals maximum shelling percentage as compared to a minimum in Shalimar $x$ KD-03 $(48.35 \%)$ in the first year whereas in the second year maximum and minimum shelling percentage was recorded with the 


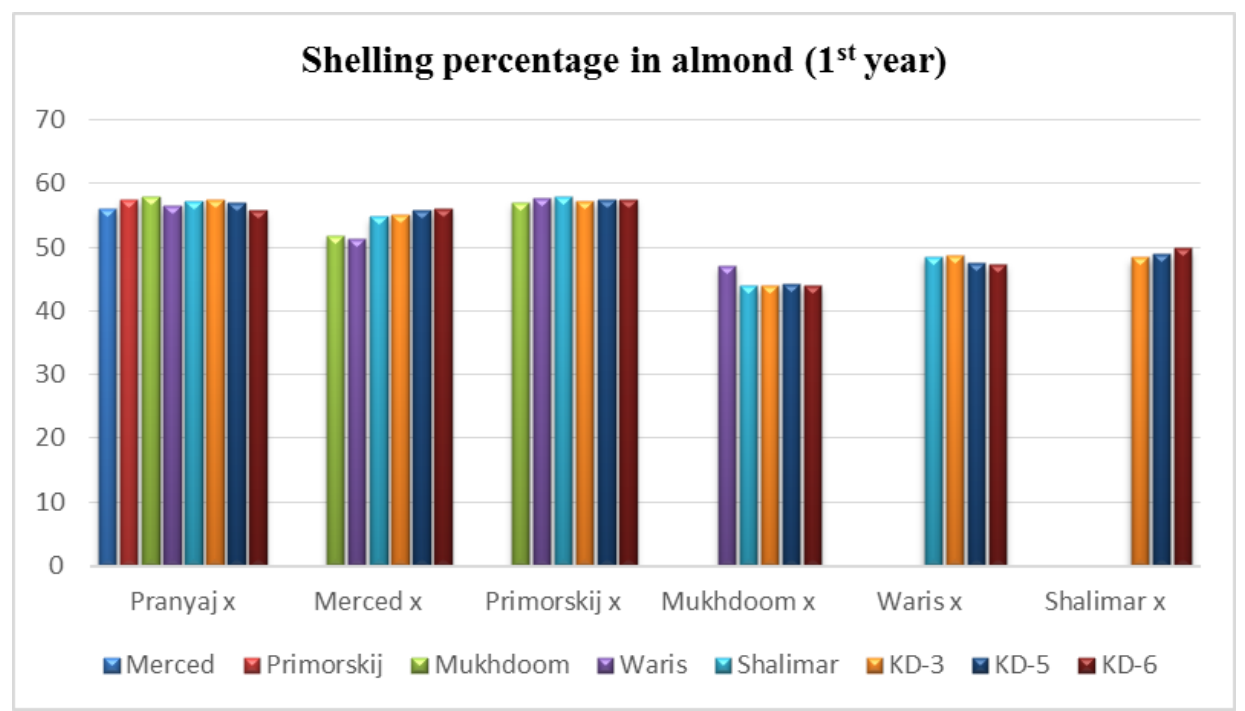

Fig. 1. Effect of pollen sources on shelling percentage in almond $\left(1^{\text {st }}\right.$ year).

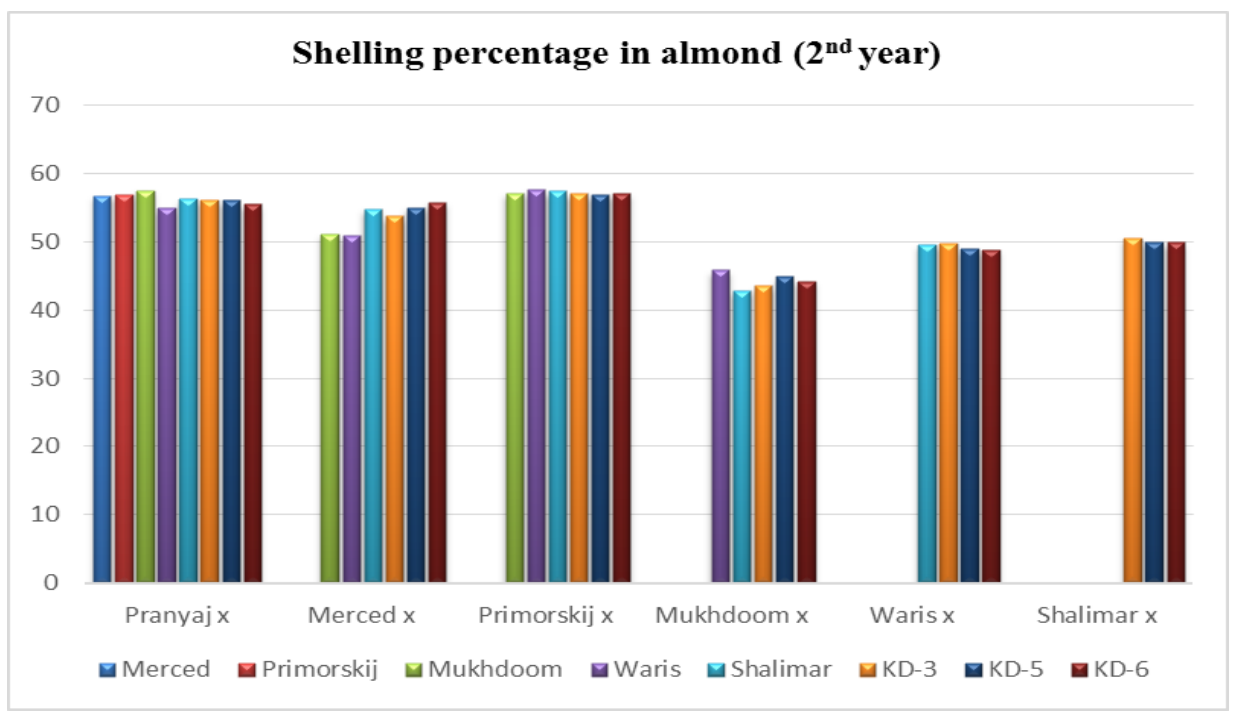

Fig. 2. Effect of pollen sources on shelling percentage in almond $\left(2^{\text {nd }}\right.$ year).

pollen source of KD-03 (50.55 \%) and KD-06 $(49.86 \%)$, respectively (Fig. 1 and 2 ).

Bahmani et al. (2003) also reported that pollination of almond with pollen of the cultivars with higher shelling percentage significantly increased shelling percentage in the recipient parent. The effect of pollen type on shelling percentage was in agreement with results previously reported in almond (Kumar and Das, 1996; Acar et al., 2016), in pistachio (Crane and Iwakiri, 1980), in hazelnut (Javadi and Gheshlaghi, 2006) and in walnut (Golzari et al., 2016).

The effects of pollen source on nut and kernel characteristics are known in several nut crops. In the present study, our results confirmed the effect of pollen on the physical characteristics of the nut and kernel of almond ( $P$. amygdalus). At the same time, further research could clarify the effect of pollen on the chemical composition of the nut.

\section{Conclusion}

From the present study, it was concluded that the pollen source on the nut and kernel characteristics of recipient varieties/selections of almond $(P$. amygdalus) revealed that the characters like nut weight, kernel weight, nut size, kernel size and shelling percentage were significantly $(p \leq 0.05)$ influenced by the donor parent. The paternal effect in the present study exhibited by differences among fruits borne on the same cultivar but developed from a different source of pollen.

\section{REFERENCES}

1. Acar, I., Yilmaz, A. and Ak, B.E. (2016). Paternal effects on fruit characteristics of some almond cultivars. CIHEAM Options Mediterraneennes 119: 29-32

2. Anonymous. (2018). Pacakage and Practices of temperate fruit crops. Directorate of Extension Educa- 
tion, SKUAST-Kashmir, p 216

3. Anonymous. (2019). Area and Production of Major Horticultural Crops in Jammu and Kashmir for year 2018-19. Directorate of Horticulture, Kashmir. Pp 1-2.

4. Bahmani, A., Gregorian, A., Valizadeh, M. and Vezvaei, A. (2002). Effect of pollen type and nature on fruit size and certain tasting characteristics of almond kernel (Prunus amygdalus Btsch). Iranian Journal of Agricultural Sciences 33: 296-298.

5. Crane, J.C. and Iwakiri, B.T. (1980). Xenia and Metaxenia in pistachio. Horticultural Science 15: 184-185.

6. Connell, J.H. (2000). Pollination of Almonds: Practices and Problems. HortTechnology 10(1): 116-119

7. Denney, J.O. 1992. Xenia Includes Metaxenia. HortScience 27(7): 722-728

8. Golzari, M., Hassani, D., Rahemi, M. and Vahdati, K. (2016). Xenia and Metaxenia in Persian Walnut (Juglans regia L.). Journal of Nuts 7(2): 101-108

9. Javadi, D. and Gheshlaghi, A.E. (2006). Effect of different pollen sources on nut and kernel characteristics of hazelnut (Corylus avellana L.). Iranian Journal of Horticultural Science and Technology 7: 15-22.

10.Kester, D.E., Gradziel, T.M. and Micke, W.C. (1994). Identifying pollen incompatibility groups in California almond cultivars. Journal of American Society for
Horticultural Science 119(1): 106-109.

11.Kumar, K. and Das, B. (1996). Studies on xenia in almond (Prunus dulcis (Miller) D.A. Webb). Journal of Horticultural Science 71: 545-549.

12.Marquard, R.D. (1988). Outcrossing rates in pecan and the potential for increased yields. Journal of the American Society for Horticultural Science 113: 84-88

13.Rahemi, M. and Javadi, D. (2001). Effect of pollen source on nut and kernel characteristics of hazelnut. Acta Horticulturae 556: 371-376.

14.Sharafi, Y., Karimi, M. and Ghorbanifar, M. (2010). Study of pollen tube growth, cross-compatibility and fruit set in some almond genotypes. African Journal of Plant Sciences 4(5): 135-137.

15.Sharma, M.K. and Joolka, N.K. (2000). Effect of soil and foliar application of nitrogen on the leaf nutrient status of almond (Prunus amygdalus Batsch.). Journal of Horticultural Sciences 29(3/4): 191-192.

16.Snedecor, G.W. and Cochran, W.G. (1994). Statistical Method. English edition. First East-West Press edition, New Delhi pp 503.

17.Vezvaei, A. and Jackson, J.A. (1995). Effect of pollen parent and stages of flower development on almond nut production. Australian Journal of Experimental Agriculture 35: 109-113. 